\title{
Application of Customer Lifetime Value Model in Make-to-Order Manufacturing
}

Oya I. Tukel

Cleveland State University, o.icmeli@csuohio.edu

Ashutosh Dixit

Cleveland State University, a.dixit1@csuohio.edu

Follow this and additional works at: https://engagedscholarship.csuohio.edu/bus_facpub

Part of the Marketing Commons

How does access to this work benefit you? Let us know!

Publisher's Statement

This article is (c) Emerald Group Publishing and permission has been granted for this version to appear here 10.1108/JBIM-04-2013-0099. Emerald does not grant permission for this article to be further copied/distributed or hosted elsewhere without the express permission from Emerald Group Publishing Limited

\section{Original Published Citation}

Tukel, O. I., Dixit, A. (2013). Application of Customer Lifetime Value Model in Make-to-Order Manufacturing. Journal of Business \& Industrial Marketing, 28(6), pp. 468-474.

This Article is brought to you for free and open access by the Monte Ahuja College of Business at EngagedScholarship@CSU. It has been accepted for inclusion in Business Faculty Publications by an authorized administrator of EngagedScholarship@CSU. For more information, please contact library.es@csuohio.edu. 


\title{
Application of customer lifetime value model in make-to-order manufacturing
}

\author{
Oya I. Tukel and Ashutosh Dixit \\ Cleveland State University, Cleveland, Ohio, USA
}

\begin{abstract}
Purpose - The applicability of the customer life time value (CLV) concept goes beyond consumer markets. Specifically, the purpose of this paper is to show how a make-to-order manufacturing company in a supply chain can set customer-focus manufacturing strategies using CLV.

Design/methodology/approach - Data from an integrated steel plant is used to calculate the life time value of customers based on the past value, the potential value, and their loyalty. The past value of a customer is based on the historical data and the future value of a customer is then forecasted. The loyalty index of a customer is determined by survey results.

Findings - In general, it was found that the CLV for the most valuable customers increases exponentially and the top 28 percent of customers constitute 80 percent of the total value of all customers.

Research limitations/implications - This study focuses on make-to-order manufacturing organizations and the three strategies suggested for business process improvement need to be re-evaluated for make-to-stock or mass production.

Practical implications - Based on these results, the authors suggest three strategies for business process improvement and revenue growth for the plant.

Originality/value - This study constitutes an initial effort to develop a CLV model for make-to-order manufacturing organizations for improving plant performance. The model links customers with not only the front office functions but also with ERP systems. Organizations that are part of value chains can benefit significantly from CLV applications.
\end{abstract}

Keywords Operations and production management, Process management, Business improvement, Manufacturing industries, Customer lifetime value, Make-to-order, Business process improvement

Paper type Case study

Customer satisfaction became part of every business process and crafting new business processes with the help of technology in order to acquire and retain the most profitable customers is gaining interest among traditional manufacturing organizations (Anderson et al., 1994). Customer relationship management (CRM) has become a new branch of learning in business management (Venkatesan and Kumar, 2004; Reinartz and Kumar, 2000, 2002, 2003). There has been considerable effort on developing CRM strategies for organizations such as banks and insurance, and telecommunication companies, where the customer is an individual and marketing efforts are targeted towards clusters of these individuals possessing similar characteristics. Data mining tools are typically employed to define customer characteristics and to identify their buying trends (Gupta and Lehmann, 2003, 2005; Gupta et al., 2004).

When companies evaluate their relationships with other companies as their customers, however, business practices change considerably. Business markets are distinct from consumer market as they have fewer but larger customers, and customers have often specialized needs. Companies can communicate value in these business markets by educating buyers not only about tangible financial benefits, but also about non-tangible financial benefits, tangible non-financial benefits, and non-tangible non-financial benefits, and linking these to the executives who desire them (Bowman and Narayandas, 2004; Narayandas, 2005; Narayandas et al., 2005). Usually a written contract between the buyer company and the seller company determines the type and the intensity of the relationship. Manufacturing companies in the upstream value chain systems are good examples of businesses where important aspects of CRM such as up-selling and cross selling might not be applicable for improving customer value and retention, rather, the financial strength, the length of the contractual relationship, the ability to integrate their processes with that of buyer's, and purchase volume might be more critical in determining customer value. A major question is how does a company choose a high-value business customers and maintain profitable relationships with them? Committed customers are not only profitable but may also serve as advocates for a company (Lacy and Morgan, 2009).

In the literature there is limited work discussing the issues regarding the integration of CRM to manufacturing business processes. Although buyer-supplier relationships are commonly studied, typically the focus is on their contractual relationships. The scope of CRM is beyond contractual relationships. As Kim et al. (2003) described, "CRM is about managing business interactions with customers by combining business processes and technologies that seek to understand a company's customers" (p. 6). CRM requires company wide, cross-functional, customer-centric process re-engineering (Chen and Popovich, 2003). It links customers with not only the front office functions (sales and marketing departments) but also with back office functions (operations). Various manufacturing companies, especially 
the ones with make-to-order strategies, that are part of value chains can benefit immensely from CRM applications. In a make-to-order business model customer relationship development is vital, since each order is made to meet customer specifications and requires high customer contact throughout the production process.

In this study we address issues regarding the business to business customer relationship development in a make-toorder manufacturing system by developing a life time value model. The model is based on customer value determination and is tested using data from an integrated steel plant. A discussion on how plant delivery performance can be improved by the model is also provided.

In the next section we provide a literature review of customer value determination in CRM applications. Next we describe the make-to-order business environment in a supply chain. Then, we introduce the life time value model and show how it can be used in an integrated steel plant. The resulting sales and manufacturing strategies based on the analyses are presented, followed by conclusions.

\section{Customer lifetime value}

In customer relationship management, customer lifetime value (CLV) determination is important in order to understand and evaluate a company's relationship with its customers. Various studies in the literature offer business models, formulations, and guidelines in determining CLV. Jain and Singh(2002) provide a comprehensive review of the CLV literature. In their paper, they review the studies covering CLV calculations, customer base analysis, and decision support models. Most of the studies on CLV calculations focus on the Net Present Value of a customer gained over the lifetime of that customer using cost of customer acquisition and retention, and the revenue stream from the customer (Berger and Nasr, 1998; Bitran and Mondschein, 1996; Jackson, 1994). The lifetime is considered to be past period that the customer stayed as the company's customer. In a recent study by Hwang et al. (2004), the calculation of a CLV includes the customer's potential value and the loyalty of that customer. The potential value of a customer is defined as the expected profit that can be obtained from the customer in a certain time period. Customer loyalty is defined as the probability that the customer would be likely to remain a customer of a company, and is equivalent to (1-churn rate). In this paper the CLV model we suggest is an adaptation of Hwang's LTV model. In our model we factor in uniqueness of make-to-order manufacturing systems and business to business relationships.

Studies focusing on customer base analysis examine which customer segment to attract and retain, and the link between a company's profitability and customer value (Jain and Singh, 2002). The decision support models offer frameworks in which informed decisions about the level of relationships with customers can be made (Dwyer, 1997; Mulhern, 1999). In general, as Jain and Singh (2002) conclude, it is hard to make definite conclusions about the effectiveness of improved customer relations using the suggested models since many have not been tested in practice.

\section{Make-to-order strategy and supply chain}

Supply chains play a critical role in customer value generation. Suppliers, manufacturers, warehouses and retailers coordinate their businesses in order to meet the demand, reduce cost, and satisfy their demanding customers. In this system many different types of processes are used and the process strategy defines the level of relationship a company is willing to form with its customers. Manufacturers and suppliers produce in response to a customer order (make-to-order), or make products to stock, anticipating that demand will occur (make-to-stock). In a make-to-order strategy jobs are associated with customers and the process has flexibility for product customization. Production begins after a definite order is received from a customer and thus customers must wait to have their orders filled. The total waiting time, which includes the delivery time, is a concern for sellers since there is a threshold waiting time beyond which buyer companies will defect (Cachon and Terwiesch, 2006). Buyer companies in supply chain typically do not carry inventories to buffer their production schedules and any delays impact delivery performances of other businesses downstream in the chain. Accordingly, it is important to combine business processes and technology among chain partners to improve the delivery performance, and thus customer relationships.

\section{A case study}

In order to demonstrate how the CLV concept can be used to improve customer relationships in a make-to-order system, we collected and analyzed data from an integrated steel plant in the US The plant partners with a number of supply chain systems and supplies customized steel coils to automotive part manufacturers, service centers, and construction companies. The plant has all the functions to produce primary steel:

- iron production;

- steel production; and

- coil production.

The production strategy at the plant is make-to-order. As many as 84 different grades of steel, with different width and gauge sizes in five different finishing forms, can be produced. The three most common finishing forms are hot rolled, cold rolled, and galvanized coils. The work flow is a pull method in which a customer's order triggers the production. At Iron Producing, the iron ore is melted with coke and limestone in a blast furnace to produce hot metal (molten iron). Then the hot metal is transported from the blast furnace to the hot metal transfer ladle, and carried to the Steel Making facility where the Basic Oxygen Furnace (BOF) is. The scrap, hot metal and alloys are charged into the BOF vessel to produce the exact grade of steel required. In the next stage of production the steel from the BOF is loaded to a steel transfer ladle, and transferred to the ladle metallurgy facility (LMF). At the LMF the chemistry of the steel is adjusted and it is transferred to the continuous caster. The steel flows from the tundish to adjustable molds. Once the steel solidifies in the molds, it is cut into specified lengths of slabs according to customer specifications and shipped to the hot mill for coil production. At the coil production, the slabs that require further processing are reheated to rolling temperatures in the hot strip mill and rolled to the customer's width, gauge and length. The coil sheet's thickness can be further reduced by 
cold rolling (rolling in the cold roll mill at room temperature). At the cold mill, full hard and full finish coils are produced according to customer's specifications. Cold rolls can also be zinc coated in a galvanizing plant to make galvanized plates. In general, the inventory levels are kept at minimum (typically as slab) although the biggest customer, an automotive part producer, works in a just in time environment and requires two week's worth of inventory to be kept at the plant at all times.

In Figure 1 the flowchart depicting the general business process is given. The shaded processes are where the communication with the customers takes place. As can be seen from the chart the customer touch points are traditional, at the front end of the business, and no interaction takes place at the process design, validation, or production stages.

The plant has a broad industrial customer base, from small local firms to large assembly plants. Most customers do not have pre-contracted agreements with the plant. Accordingly, the plant has a current policy of accepting orders from any business, as long as the order size meets the minimum batch size. It is the customer's responsibility to provide the transportation for order pickups (i.e. delivery is FOB factory). Given their make-to-order strategy, diverse customer base, and non-contractual relations with buyers, the company has difficulty setting accurate promise dates and being able to deliver on these days. The customer survey results indicate that there is high customer dissatisfaction with the plant's on-time delivery performance. There is no effective customer relationship management effort in the plant to date, mainly because of market distortions that encouraged many industrial steel buyers/sellers to buy/sell steel in the spot market.

\section{Demand characteristics}

In a make-to-order environment the biggest challenge is to predict the demand pattern. In the steel plant, regardless of the product type, there is considerable variation in the demand pattern (see Table I). For example, in a particular week as low as 9 or as high as 508 hot roll orders are placed with an order quantity of as low as 633 tons and as high as 80,000 tons. Some of this variation can be explained by the company's interest in the spot market, non-contractual sales agreements where market pressures determine pricing.

Table I Demand characteristics

\begin{tabular}{lrrrr}
\hline & Weekly average & Standard deviation & Min & Max \\
\hline $\begin{array}{l}\text { Hot roll } \\
\text { Order quantity } \\
\text { No. of orders }\end{array}$ & 29,484 & 14,622 & 633 & 79,943 \\
& 234 & 96 & 9 & 508 \\
$\begin{array}{l}\text { Cold roll } \\
\text { Order quantity }\end{array}$ & 6,685 & 4,578 & 19 & 28,555 \\
No. of orders & 77 & 41 & 1 & 200 \\
& & & & \\
$\begin{array}{l}\text { Galvanized } \\
\text { Order quantity }\end{array}$ & 642 & 625 & 22 & 3,264 \\
No. of orders & 10 & 9 & 1 & 47 \\
& & & & \\
$\begin{array}{l}\text { Total } \\
\text { Order quantity }\end{array}$ & 36,527 & 16,354 & 669 & 84,012 \\
No. of orders & 317 & 121 & 10 & 616 \\
Note: ${ }^{\text {Tons }}$ & & & & \\
\hline
\end{tabular}

Figure 1 Integrated steel plant business process

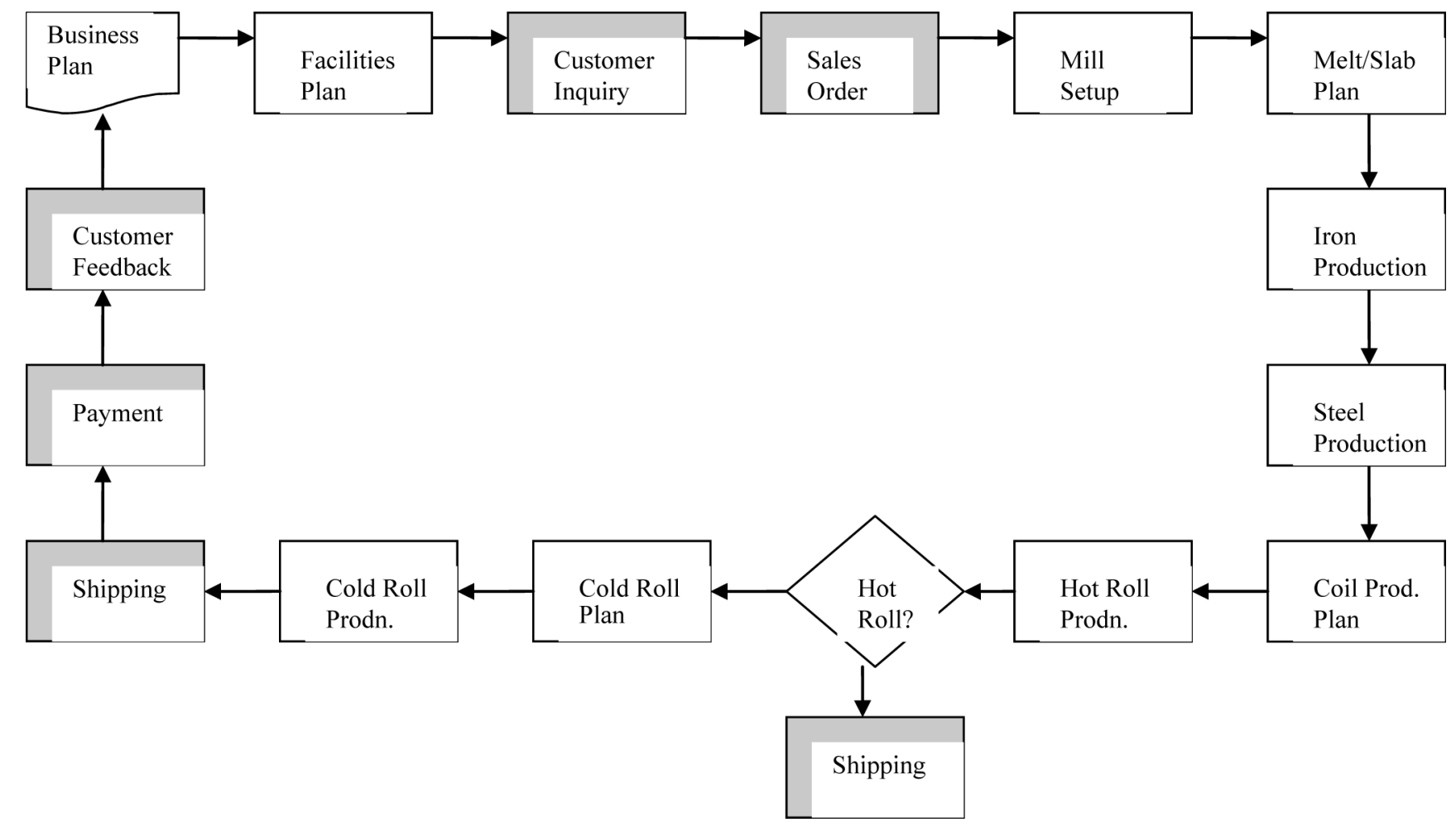


Although the company can benefit from price spikes in the market, the unplanned customer orders imposed to the production system impact capacity allocation and delivery performance, and in turn the company's contractual relations with other customers.

\section{Application of the life time value model for improving customer relationships}

Up to now, there have been limited efforts at the plant to understand and retain the most valuable customers. This is mainly because the customer defection rate is low. According to a customer survey, although almost all customers complain about late deliveries, only 15 percent indicated that they might not work with the plant in the future. Many factors such as proximity to the plant (low transportation cost) and the availability of customized products were offered as reasons for their continuous relationship. However, this tendency might change in the future.

Because of the market changes due to foreign competitors, the efficiency and improved business interactions with customers will be vital for the survival of the plant in the future. Although there are many CRM methods available for better managing and structuring the customer base, we believe that customer base CLV methods are more appropriate to use in a make-to-order system. Customer base CLV analysis look at each customer individually and determine the value of a customer by taking into consideration the stochastic behavior of that customer. In a make-to-order manufacturing system in a supply chain typically the customer base is small in size. The recent trend of establishing tier relationships with suppliers decreased the number of suppliers a company works with considerably. The small customer base enables sellers to observe each customer's behavior, a prerequisite for CLV determination. Furthermore, in make-to-order systems more accurate projections about customers' purchasing behavior, and in turn, more reliable customer value can be determined, since type, quantity, and timing of purchase do not completely depend on the buyer. The steel plant has a customer database consisting of 205 businesses that can be grouped into service centers, end users, and automotive part producers, of which 72 have ordered at least once in the past three years. The customers' purchasing behavior in each group is predictable to a certain extend by observing the demand pattern in the industry to which they belong. For example, service centers order high quantities of hot roll coils in many different grades. Automotive part producers typically work in a just-in-time environment and order small batches of very specific grades. End users such as the ones in the construction industry have seasonal demand for steel that is low during winter months and high in spring time.

However, not all the plant customers are equally profitable to work with and the customer relationship needs to be shaped based on the value of a customer. Currently, the plant has a close to 100 percent customer order acceptance policy. Regardless of whether the customer has a contract or not, whether the customer is "loyal" (has been buying from the plant for at least three years) or not, the sales department accepts their orders. Obviously, the 100 percent customer order acceptance policy diminishes the overall customer satisfaction levels and reduces the profitability of the plant. We suggest that understanding the value of customers and offering different levels of service based on this value will improve overall performance.

\section{Customer value}

One of the important issues in CRM is "how large are the profits a given customer can contribute to a company?" (Hwang et al., 2004). Typically, the life time value of a customer has three components: the past value, the potential value, and the customer loyalty. In this study we define the past value of a customer as the total profit contribution of that customer in the last three years. The reason for choosing the last three years for the analyses is because of the lack of availability of accurate data prior to three years. The potential value of a customer is defined as the expected profit that can be obtained from the customer in the next two years. The reason for only including the next two years in calculating the potential value of a customer is mainly because of high variation in demand pattern in the past. It makes future demand forecasts highly unreliable. Finally, customer loyalty is defined as the probability that a customer would be likely to remain a customer of the plant.

\section{Computation of CLV for steel customers}

In our analysis we collected data on the customers ordering the three most common product types: hot roll, cold roll, and galvanized coils. A total of 74 percent of the orders are for hot roll, 24 percent for cold roll, and 2 percent for galvanized coils.

The life time value of customer $j$ is calculated as:

$$
C L V_{j}=\left(P P C_{j}\right)+L I_{j}^{*}\left(F P C_{j}\right)
$$

where:

- $\quad P P C_{j}$ is the past profit contribution of customer $j$.

- $F P C_{j}$ is the future profit contribution of customer $j$.

- $L I_{j}$ is the loyalty index of customer $j$.

The past profit contribution $\left(P P C_{j}\right)$ is calculated as:

$$
P P C_{j}=\sum \sum_{i t} p_{i t^{*}} q_{i t}
$$

where:

- $\quad p_{i t}$ is the net profit contribution of product type $i$ in year $t$.

- $\quad q_{i t}$ is the total sales(tons) of product $i$ sold to customer $j$ in year $t$ where $i=1,2,3$ for hot roll, cold roll, or galvanized products, and $t=1,2,3$.

Future profit contribution $\left(F P C_{j}\right)$ is calculated as:

$$
F P C_{j}=\sum \sum_{i t} F p_{i t^{*}} F q_{i t}
$$

where:

- $\quad F p_{i t}$ is the forecasted profit contribution of product $i$ in year $t$.

- $F q_{i t}$ is the forecasted total sales (tons) of product $i$ sold to customer $j$ in year $t$ where $i=1,2,3$ for hot roll, cold roll, or galvanized products, and $t=1,2$.

\section{Computational results}

Total sales volumes $(F q)$ are forecasted by using the stepwise auto regression method, while future profit contributions are forecasted by using the three-year moving average method. The highest weight of 3 is given to the most recent data. The variables include: $L I$ is the loyalty index and indicates the probability of a customer not defecting in the future. LI ? 
$[0,1]$ for all customers where $L I_{j}=0$ indicates customer $j$ with no future intentions of repeat buying and $L I_{j}=1$ indicates long term contracted customers with 100 percent possibility of staying. In the literature Schmittlein et al. (1987) proposed the Pareto/NBD model for calculating the probability that a customer will be active in the future. The model requires the number and timing of purchases as inputs and predicts the customer groups who possibly will be active. The sophisticated nature of the model makes it difficult to use in the plant. In our case, we have used three values for LI, 0.25, 0.50 , and 0.88 . The customer survey results were used to determine the lower (0.25) and upper bound (0.88) values of LI. Customers with negative $F q$ values are assigned $L I$ of 0.25 since their purchasing trend indicate that they might not be buying from the plant and thus they might defect in near future. The customers with high $F q$ values are likely to stay and we assigned then an $L I$ of 0.88 . Any other customer with positive $F q$ are given $L I$ values of 0.50 indicating that it is equally likely that these customers will stay or defect.

Based on the CLV values thus computed we have ranked the 72 customers which have continuously ordered in the past three years (Figure 2). The top 20 of these life time valued customers are listed in Table II. As the figure indicates the CLV values for the more valuable customers increase exponentially. The sum of the CLV values for the 20 best customers constitutes 80 percent of the total value of all customers. This result has important implications, suggesting the importance of focusing on delivery performance for these customers.

Table II summarizes the customer profiles for top $20 \mathrm{CLV}$ customers. The top two most valued customers work with the plant based only on pre-negotiated contracts, while three customers (ranked 17, 18 and 20) use only the spot market. The rest use a combination of spot market and contractual orders. It should be a concern that 90 percent of the most valuable customers buy in the spot market with no long-term commitment to the plant.

\section{Strategies}

Like many businesses today, the steel plant is faced with global competitive challenges that necessitate re-evaluation and improvement of current business processes. There are three areas that the steel plant needs to focus on, which are correlated: production process improvement, better management of customer relations (in particular customer

Figure 2 Ranked life time values of plant customers

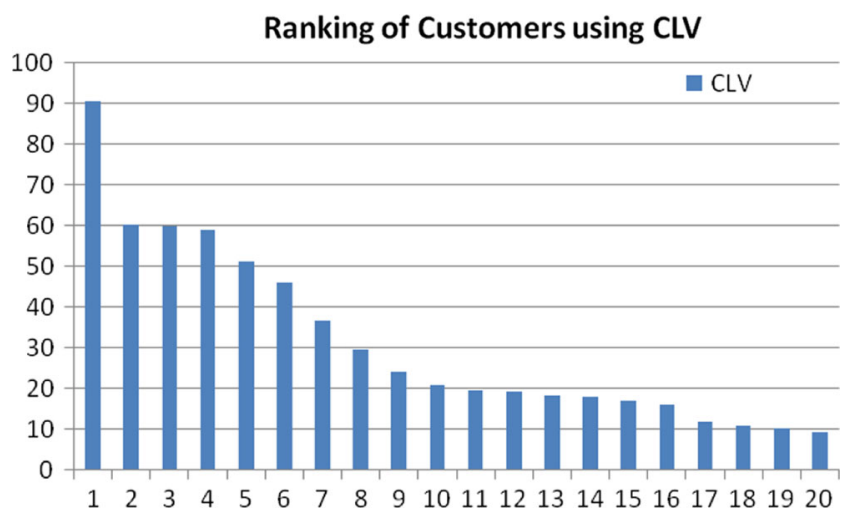

satisfaction), and investment in information technology that will strengthen the interactions between sales, production, and the customer.

We have analyzed the demand pattern, customer characteristics, and delivery performance using the company's last three years data, and determined the CLV of each customer. The next step is to use this information to develop customer relationship strategies.

\section{Strategy 1. Develop an order acceptance policy based on customer relations}

The steel plant has been serving an array of customers with an almost 100 percent order acceptance policy. Today, the demand for high quality, customized products packaged with better and faster service, forces supply chain partners to be more efficient in production, and more reliable in delivery performance. To achieve the latter goal the high variation in the demand pattern needs to be smoothed out. This can be accomplished by reducing the number of different grade offerings, encouraging the customers to get into contractual relationships (rather than spot market selling) which will help the company with accurate forecasting of future demand, and in times of limited capacity, postponing the acceptance of orders coming from less valued customers. A possible move towards batch production with some standardization in product variety will reduce sizeable variations in demand and thus will improve the predictability of customers' demand pattern.

\section{Strategy 2. Develop manufacturing strategies based on customer segmentation and CLV}

In our study we had limited data regarding customers' business profile, which limited the quality of the segmentation study. The results of a cluster analysis were evaluated to determine the distinguishing characteristics of the most valued customers. We used active customer accounts in the analysis and came up with four heterogeneous customer groups. The members of the first group are profiled as mostly service centers that pay higher per ton of steel compared to other customers and their order quantities are typically small. The second group commonly order hot roll coils and they order larger width coils compared to other customers. The members in the third group are both service centers and end users and compared to other customers, this group orders coils in small widths. A total of 19 out of 20 of the top lifetime valued customers belong to this last group. This group commonly orders a unique grade in large quantities. Since product type and size mainly differentiate customer groups, the plant can keep inventories of unique grades and sizes of steel in slab forms. Inventories would be a buffer for possible delays and would increase the likelihood of meeting promise dates.

\section{Strategy 3. Set a 100 percent customer satisfaction goal for the top 20 life time valued customers}

CRM stresses the need to develop long-term relations with the most valued customers. It is important to accurately identify who these customers are and develop policies to retain them. For the steel plant, we used the CLV model and ranked the customers based on their life time value. The top 20 life time valued customers (27 percent of active customer base) constitute 80 percent of the value of all customers. Obviously, the company should spend every effort to retain 
Table II Top 20 most valued customers

\begin{tabular}{|c|c|c|c|c|c|c|c|c|c|c|}
\hline Rank & $\begin{array}{l}\text { Customer } \\
\text { number }\end{array}$ & $\begin{array}{l}\text { End } \\
\text { user }\end{array}$ & $\begin{array}{l}\text { Service } \\
\text { center }\end{array}$ & Automotive & Spot & $\begin{array}{l}\text { Pre-negotiated } \\
\text { contracts }\end{array}$ & $\begin{array}{l}\text { Loyalty } \\
\text { index }\end{array}$ & $\begin{array}{l}\text { Past contribution } \\
\text { (in million \$) }\end{array}$ & $\begin{array}{l}\text { Potential contribution } \\
\quad \text { (in million \$) }\end{array}$ & $\begin{array}{c}\text { CLV } \\
\text { (in million \$) }\end{array}$ \\
\hline 1 & 20,700 & & & $\times$ & & $A C$ & 0.88 & 25.6 & 73.8 & 90.6 \\
\hline 2 & 525 & & $x$ & & & $A C$ & 0.88 & 21.5 & 43.9 & 60.2 \\
\hline 3 & 521 & & $x$ & & SS & SC & 0.88 & 23.8 & 40.9 & 59.9 \\
\hline 4 & 501 & $x$ & & & & MC & 0.88 & 28.9 & 34.2 & 59.1 \\
\hline 5 & 503 & & $x$ & & SS & SC & 0.88 & 20.3 & 35.0 & 51.1 \\
\hline 6 & 508 & & $x$ & & SS & SC & 0.88 & 27.2 & 21.4 & 46.1 \\
\hline 7 & 964 & $x$ & & & & MC & 0.88 & 15.4 & 24.3 & 36.8 \\
\hline 8 & 534 & & $x$ & & MS & & 0.88 & 21.5 & 9.1 & 29.6 \\
\hline 9 & 505 & & $x$ & & MS & & 0.88 & 17.2 & 7.7 & 24.1 \\
\hline 10 & 1,033 & & $x$ & & MS & & 0.88 & 9.1 & 13.5 & 21.0 \\
\hline 11 & 524 & & $x$ & & MS & & 0.50 & 15.1 & 8.7 & 19.5 \\
\hline 12 & 1,200 & & $x$ & & MS & & 0.88 & 6.7 & 14.2 & 19.2 \\
\hline 13 & 595 & & $x$ & & & MC & 0.88 & 10.6 & 8.6 & 18.2 \\
\hline 14 & 509 & & $x$ & & & MC & 0.88 & 9.4 & 9.9 & 18.1 \\
\hline 15 & 522 & & $x$ & & MS & & 0.50 & 13.6 & 6.8 & 17.0 \\
\hline 16 & 556 & & $x$ & & MS & & 0.50 & 12.0 & 7.9 & 15.9 \\
\hline 17 & 798 & & $x$ & & AS & & 0.88 & 8.7 & 3.6 & 11.9 \\
\hline 18 & 571 & & $x$ & & AS & & 0.50 & 8.1 & 5.7 & 10.9 \\
\hline 19 & 592 & & $x$ & & MS & & 0.88 & 3.9 & 7.3 & 10.4 \\
\hline 20 & 663 & & $x$ & & AS & & 0.88 & 6.9 & 2.7 & 9.3 \\
\hline
\end{tabular}

Notes: AC - always buy contracted; AS - always buy spot; SS - sometimes buy spot; SC - sometimes buy contracted; MS - mostly buy spot; MC - mostly buy contracted

these customers and develop long term relations with them, although most of these valued customers are currently not interested in long term relationships, indicated by their interest in spot market.

On the other hand, 73 percent of the customers are not as profitable but they repeatedly buy from the plant. The question is then what type of relations and satisfaction levels should be set for these customers? In general, the cost of satisfying every customer at 100 percent level is exponentially costly and in many cases unnecessary. We suggest the company to identify stages of relationships using the CLV rankings we developed, and manage these relations using information technology.

\section{Conclusions}

With this study we show that CRM can be applied to maketo-order manufacturing systems. The CLV approach can be used to improve business processes and the customer relationships in a business to business environment. One of the main challenges with CRM applications is the availability of data about customers. In our study we had limited data regarding the customers' business profile which limited the scope of the study. Because the steel plant's customers prefer to buy in the spot market the plant spent limited effort collecting data on customers. However, in any CRM implementation, it is imperative to collect data on customers and create a comprehensive database.

Recognizing the importance of customers in supply chains for efficiency is only a first step. Partners in a supply chain must develop sound customer focused strategies and then synchronize their business processes, people, and technology to translate these initiatives into improvement in revenues.
Today, many manufacturing companies are still not convinced that customer loyalty is linked to their sustainable growth. They would rather invest in manufacturing technologies, automated systems, and ERP for revenue growth. With this study we demonstrate that concepts such as life time value can be applicable in a traditional manufacturing setting where customers are industrial buyers, rather than individuals, and manufacturing strategies can be built around customers for sustainable growth.

\section{References}

Anderson, E.W., Fornell, C. and Lehmann, D.R. (1994), "Customer satisfaction, market share, and profitability: findings from Sweden", fournal of Marketing, Vol. 58 No. 3, pp. 53-66.

Berger, P. and Nasr, N. (1998), "Customer lifetime value: marketing models and applications", fournal of Interactive Marketing, Vol. 12 No. 1, pp. 17-30.

Bitran, G. and Mondschein, S. (1996), "Mailing decisions in the catalog sales industry", Management Science, Vol. 42 No. 9, pp. 1364-1381.

Cachon, G. and Terwiesch, C. (2006), Matching Supply with Demand, McGraw-Hill, Boston, MA.

Chen, I. and Popovich, K. (2003), "Understanding customer relationship management, people, process and technology", Business Process Management, Vol. 9 No. 5, pp. 672-688.

Bowman, D. and Narayandas, D. (2004), "Linking customer management effort to customer profitability in business markets", fournal of Marketing Research, Vol. 41 No. 4, pp. 433-447. 
Dwyer, R. (1997), "Customer lifetime valuation to support marketing decision making", Fournal of Direct Marketing, Vol. 11 No. 4, pp. 6-13.

Gupta, S. and Lehmann, D.R. (2003), "Customers as assets", fournal of Interactive Marketing, Vol. 17 No. 1, pp. 9-24.

Gupta, S. and Lehmann, D.R. (2005), Managing Customers as Investments: The Strategic Value of Customers in the Long Run, Wharton School Publishing, Upper Saddle River, NJ.

Gupta, S., Lehmann, D.R. and Stuart, J.A. (2004), "Valuing customers", Fournal of Marketing Research, Vol. 41 No. 1, pp. 7-18.

Hwang, H., Jung, T. and Suh, E. (2004), "An LTV model and customer segmentation based on customer value: a case study on the wireless telecommunication industry", Expert Systems with Applications, Vol. 26 No. 2, pp. 181-188.

Jackson, D. (1994), "Strategic application of customer lifetime value in the direct marketing environment", Fournal of Targeting Measurement and Analysis for Marketing, Vol. 3 No. 1, pp. 9-17.

Jain, D. and Singh, S. (2002), "Customer lifetime value research in marketing: a review and future directions", Fournal of Interactive Marketing, Vol. 16 No. 2, pp. 34-46.

Kim, J., Suh, E. and Hwang, H. (2003), "A model for evaluating the effectiveness of CRM using the balanced scorecard", fournal of Interactive Marketing, Vol. 17 No. 2, pp. 5-19.

Lacy, R. and Morgan, R.M. (2009), "Customer advocacy and the impact of B2B loyalty programs", Fournal of Business and Industrial Marketing, Vol. 24 No. 1, pp. 3-13.

Mulhern, F. (1999), "Customer profitability analysis: measurement, concentration, and research directions", Fournal of Interactive Marketing, Vol. 13 No. 1, pp. 25-40.

Narayandas, D. (2005), "Building loyalty in business markets", Harvard Business Review, September, pp. 131-138.

Narayandas, D., Lemon, K. and Rust, R.L. (2005), Customer Equity Management, Prentice Hall, Upper Saddle River, NJ.

Reinartz, W.J. and Kumar, V. (2000), "On the profitability of long-life customers in a noncontractual setting: an empirical investigation and implications for marketing", fournal of Marketing, Vol. 64 No. 4, pp. 17-35.
Reinartz, W.J. and Kumar, V. (2002), "Mismanagement of customer loyalty", Harvard Business Review, Vol. 80 No. 3, pp. 86-94.

Reinartz, W.J. and Kumar, V. (2003), "The impact of customer relationship characteristics on profitable lifetime duration", fournal of Marketing, Vol. 67 No. 1, pp. 77-99.

Schmittlein, D., Morrison, D. and Colombo, R. (1987), "Counting your customers: who are they and what will they do next", Management Science, Vol. 33 No. 1, pp. 1-24.

Venkatesan, R. and Kumar, V. (2004), "A customer lifetime value framework for customer selection and resource allocation strategy", fournal of Marketing, Vol. 68 No. 4, pp. 106-125. 